\title{
ETA ( $)$ AND PLATELET PHASES IN INVESTMENT CAST SUPERALLOYS
}

\author{
G. K. Bouse \\ Howmet Corporation Operhall Research Center \\ Whitehall, Ml 49461
}

\begin{abstract}
The occurrence of platelet phases in equiax, directionally solidified (DS), and single crystal (SC) turbine blades, vanes, and integral wheels was investigated. Examples of platelet phases in turbine components made from low carbon PWA1480, C103 (or PWA1483, AF56, or Sx792), IN792+Hf (or C101), IN939, IN6203, and GTD111 alloys were shown. For IN792+Hf, IN939 and GTD111 the phases formed internally, and for most of the alloys the phases also formed by reaction with the ceramic shell or facecoat, or from local segregation. The platelet phases were associated with casting scale or fluorescent penetrant indications. All of these alloys have 8-18 wt.\% (15-28 at.\%) $\mathrm{Ti}+\mathrm{Ta}+\mathrm{Nb}+\mathrm{Hf}$, compared to 2.3-5 wt. \% (4-11 at. \%) Al, which to some extent destabilizes the desired $\mathrm{Ni}_{3} \mathrm{Al}\left(\gamma^{\prime}\right)$ phase and promotes $\mathrm{Ni}_{3} \mathrm{Ti}(\eta)$ phase, or other platelet phases rich in $\mathrm{Ta}$, $\mathrm{Nb}$, and $\mathrm{Hf}$.
\end{abstract}

\section{Introduction}

Since 1988, the occurrence of platelet phases in turbine hardware primarily for land-base engines has increased. A case study of several turbine parts that contained these phases will be discussed: equiax and directionally solidified (DS) IN792+Hf wheels and blades; IN939 vanes; DS GTD 111 and IN6203 blades; single crystal (SC) C103 blades; and low carbon SC PWA1480 blades.

The compositions of these alloys are given in Table I [1-5]. Compared to older land-base turbine alloys such as U500, U700 and IN738, Ti, Nb, Ta, and noticeably $\mathrm{Hf}$ are included in increasing amounts for strength or corrosion considerations. During casting, these elements may segregate so that lower strength $\mathrm{Ni}_{3} \mathrm{Ti}(\eta)$, or platelet phases form in preference to the traditional $\mathrm{Ni}_{3} \mathrm{Al}\left(\gamma^{\prime}\right)$ phase.

These phases have usually been seen during casting process development. The phases were associated with the presence of scale (which can occur on either shell or core sides of the casting), or anomalies such as hot tears or other fluorescent penetrant (FPI) indications. These phases were usually found in the as-cast condition. In some cases, the platelet phases were found after a deviated process which required rejection of those castings. In most instances the

$$
\text { Superalloys } 1996
$$

normal grit blasting or belting operations removed the scale on external surfaces. However, this may not be true of internal surfaces used for weight reduction or air cooling.

To better understand these platelet phases, a study was conducted on six alloys in which the platelet phases had been reported by the casting operations.

\section{Background}

A review of the literature showed little documentation on the occurrence of platelet phases, other than topologically closed packed (TCP) phases such as $\sigma$ or $\mu$. The platelet phases that will be discussed here are different in several ways, notably they are usually visible at $<100 \mathrm{X}$ and they are present in the as-cast condition. In addition, the platelet phases can usually be eliminated by process control, as opposed to control of alloying elements. Finally, the evidence suggests that small amounts of the platelet phases can be tolerated in today's turbine engines without degradation to mechanical properties.

\section{Review of $\mathrm{Ni}_{3} \mathrm{Ti}$ Eta (n) Phase}

A review of platelet phases should start with eta $(\eta)$ phase or $\mathrm{Ni}_{3} \mathrm{Ti}$ which was identified in the late 1930's, according to The Superalloys and Superalloys II $[6,7]$. Eta has a hexagonal close-packed (HCP) structure that is non-coherent with the matrix and generally exists as large platelets which can extend across grains [8]. For awhile, the name "O'Hare" phase was used by some to describe $\eta$, because the $\eta$ platelets resembled runways at Chicago's O'Hare airport.

In castings, $\eta$ phase is seen in interdendritic regions or within $\gamma$ eutectic pools. In this form the phase confers "little benefit to the alloy and is therefore undesirable." In an environment of $\mathrm{Ni}$ and $\mathrm{Cr}$ (the "base" for most superalloys), when the $\mathrm{Ti}$ content exceeds the solubility limit of approximately 2.7 at.\% [at 25 at. $\% \mathrm{Cr}$ at $750 \mathrm{C}(1382 \mathrm{~F})$ ], $\eta$ phase of fixed composi-tion is precipitated [8, p38]. Reference $[\Theta]$ indicates that $\eta$ phase has "no solubility for other elements", however, more recent work indicates $\eta$ phase does have solubility for $\mathrm{Co}, W, \mathrm{Al}$, and $\mathrm{Cr}[10]$. Eta forms at high temperatures, but at lower temperatures there may be a solid state transformation to $\gamma^{\prime}$. 
Table I. Nominal Compositions (Wt. \%) of Superalloys Studied

\begin{tabular}{|c|c|c|c|c|c|c|}
\hline Element & $\begin{array}{c}\mathrm{IN} 792+\mathrm{Hf} \\
\text { (G101) }\end{array}$ & IN6203 & IN 939 & GTD 111 & $\mathrm{C} 103^{*}$ & $\begin{array}{c}\text { LoW C } \\
\text { PWA1480 }\end{array}$ \\
\hline Process $\rightarrow$ & Eq or DS & DS & Equiax & DS & $\mathrm{SG}$ & SC \\
\hline$c$ & 0.09 & 0.15 & 0.15 & 0.1 & 0.07 & $<0.01$ \\
\hline B & 0.015 & 0.01 & 0.01 & 0.01 & - & - \\
\hline $\mathrm{Zr}$ & 0.06 & 0.1 & 0.1 & 7 & - & - \\
\hline 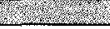 & (3) & 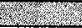 & 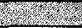 & 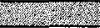 & 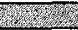 & P. \\
\hline Al & 3.4 & 2.3 & 1.9 & 3 & 3.6 & 5 \\
\hline Ti & 4 & 3.5 & 3.7 & 4.9 & 4.1 & 1.5 \\
\hline $\mathrm{Ta}$ & 4.3 & 1.1 & 1.4 & 2.8 & 5 & 12 \\
\hline $\mathrm{Hf}$ & 1 & 0.8 & - & - & - & - \\
\hline $\mathrm{Nb}$ & $=$ & 0.8 & 1 & $=$ & - & $\cdot$ \\
\hline 等 & 7. & (3) & 378\% & Wry & Pyry & 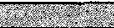 \\
\hline $\mathrm{Ni}$ & Bal. & Bal. & Bal. & $\mathrm{Bal}$. & $\mathrm{Bal}$. & Bail. \\
\hline $\mathrm{Co}$ & 9 & 19 & 19 & 9.5 & $8-9$ & 5 \\
\hline $\mathrm{Cr}$ & 12.6 & 22 & 22.5 & 14 & 12 & 10 \\
\hline$w$ & 4.3 & 2 & 2 & 3.8 & 3.8 & 4 \\
\hline Mo & 1.9 & - & - & 1.5 & 1.9 & - \\
\hline Ref. & 1 & 2 & 2 & 3 & 4,5 & 4 \\
\hline
\end{tabular}

The difference in atomic stacking between the two phases, $\eta$ and $\gamma$ is as follows:

- in $\gamma$, the close-packed planes are stacked upon each other in the ABCA... sequence, giving it the FCC structure.

- for $\eta$ phase, the stacking sequence of the close-packed plane is $A B A C \ldots$ is obtained, which produces the HCP structure $[8, p 57]$.

Mihalisin and Decker [11] showed the $\gamma^{3} \rightarrow \eta$ transformation is accelerated by deformation, and this is because the deformation facilitates the necessary shift of atomic planes described above. In the present work, the presence of cracks near platelet phases was not unusual.

Thus, in addition to a change in the lattice spacing, a shift of the atomic planes changes the stacking sequence determining $\gamma^{\prime}$ or $\eta$ phase. This is similar to the $\gamma^{\prime \prime}$ (body centered tetragonal) $\rightarrow \delta \mathrm{Ni}_{3} \mathrm{Nb}$ (orthorhombic) transformation that occurs in IN718.

Beneficial Effects of $\eta$ Phase. Eta has some beneficial effects in wrought alloys like A286 for structure control during forging. Because the transformation $\gamma \rightarrow \eta$ occurs above $650 \mathrm{C}$ (1200F), the upper service temperature of A286 is defined by this transformation [7]. Eta phase is also found in high-Fe wrought superalloys like IN706 and IN901.

Deleterious Effects. Eta phase is known to be brittle with little strain tolerance [6,9]. Since $\eta$ is non-coherent with the matrix, it may weaken the structure. However, when intergranular $\eta$ precipitated in IN901 with long exposure times at 730C (1350F), neither strength nor ductility was affected. When $\eta$ precipitated as cells (like pearlite) at grain boundaries, notch stress rupture strength and creep ductility was reduced. When $\eta$ was precipitated intergranularly, in Widmanstätten fashion, stress-rupture strength but not ductility was reduced. Thus, when $\eta$ phase precipitates from the matrix, the general experience has been some reduction of one or more mechanical properties. A summary of these observations are presented in Table II above.

For IN792+Hf castings discussed in [1], Fiedler mentioned that " $\eta$ phase is a stable constituent and cannot be removed
Table II. Summary of Observations For $\eta$ and $\delta$ Phases

\begin{tabular}{|c|c|c|}
\hline Morphology & Shape & Potential Problems \\
\hline Precipitates & $\begin{array}{l}\text { Tiny spheres usually } \\
\text { only visible with SEM } \\
\text { or TEM. }\end{array}$ & May not cause a problem. \\
\hline Cells or cellular & Pearlitic & $\begin{array}{l}\text { Can lower notched stress } \\
\text { rupture strength. }\end{array}$ \\
\hline Widmanstätten & $\begin{array}{l}\text { Thin acicular needles } \\
\text { intersecting at regular } \\
\text { angles. }\end{array}$ & $\begin{array}{l}\text { Reduces stress rupture } \\
\text { strength but not ductility. }\end{array}$ \\
\hline $\begin{array}{l}\text { Platelet or } \\
\text { globular, } \\
\text { including } \eta \text { or } \delta \\
\text { phases }\end{array}$ & $\begin{array}{l}\text { Some are parallel } \\
\text { and others intersect } \\
\text { at varying angles. }\end{array}$ & $\begin{array}{l}\text { Platelets are associated with } \\
\text { loss of RT tensile or stress } \\
\text { rupture strength or ductility, } \\
\text { and cracking. Delta phase } \\
\text { is also associated with scale } \\
\text { at core or shell surfaces, } \\
\text { incipient melting, and } \\
\text { recrystal-lized grains. }\end{array}$ \\
\hline
\end{tabular}

by solutioning at temperatures below the incipient melting point. Temperatures of $1190 \mathrm{C}(2175 \mathrm{~F})$ will only round-off the corners of an otherwise very angular appearance.... $\eta$ is most often seen in heavy sections, so that time for segregation to occur is an important factor in control of $\eta$." Freeman also notes that $\eta$ can be found in the hubs of wheels or in alloys like IN792 that contains high levels of $\mathrm{Ti}$ and $\mathrm{Ta}[7, \mathrm{p} 432]$.

Elements Involved. It is well known that $\mathrm{Ni}$ and $\mathrm{Al}$ promote the $\mathrm{Ni}_{3} \mathrm{Al} \gamma$ phase. This $\gamma$ phase has also liberally been described as $\mathrm{Ni}_{3}(\mathrm{Al}, \mathrm{Ti}, \mathrm{Nb}, \mathrm{Ta})$. But as the sum of $\mathrm{Ti}+\mathrm{Nb}+\mathrm{Ta}$ exceeds $\mathrm{Al}$, the formation of $\eta$ or platelet phases are favored. Some platelet phases are formed directly from the liquid, while others may have transformed from the $\gamma$ eutectic pools.

Fiedler [1] notes that $\mathrm{Hf}$ promotes $\eta$ phase. However, $\mathrm{Hf}$ also readily forms $\mathrm{Ni}_{5} \mathrm{Hf}$, which in castings can be found with platelet and other eutectic phases. He also mentions that increased $\mathrm{C}$ reduces $\eta$. For example, $\eta$ readily formed in IN792+ Hf parts when the $\mathrm{C}$ was lowered from $0.15 \mathrm{wt} \%$ to $0.08 \mathrm{wt} . \%$ (this is also discussed later). In [6 (p127), and 7 (p111)], Sims et. al. mention that the addition of trace amounts of $B$ will retard the formation of $\eta$ phase. In the same publication [6 (p127)] the addition of Si was stated to reduce $\eta$ phase. However, by the time [7] was published, the effect of Si was not mentioned. In a paper by Decker [12], W is also said to retard the formation of $\eta$ phase. Willemin [10] notes that "above $1250 \mathrm{C}$ (2282F), W becomes totally insoluble while the solubility of $\mathrm{Cr}$ is greatly reduced."

\section{Identification of Other Platelet Phases}

There has not been much discussion in recent literature about platelet phases. However, findings by Howmet researchers, which will be discussed later, have identified an orthorhombic platelet phase, tentatively identified as $\delta$, or $\mathrm{Ni}_{3}$ Ta phase [13]. Besides containing $\mathrm{Ta}$, this platelet phase has been found to contain measurable amounts of $\mathrm{Al}, \mathrm{Ti}, \mathrm{Hf}$, and $\mathrm{Nb}$, as well as $\mathrm{Co}$ and $\mathrm{Cr}$. Work by [10] does not specifically describe platelet phases, but includes phase relationships of interest to the present work. Finally, Chinese researchers [14], show that $P, Z r$, and Si may be responsible for increasing the amount of eutectic or other solidification segregation occurring in castings. 


\section{Technical Approach}

The morphology of the platelets was analyzed with optical metallography and with a Topcon scanning electron microscope (SEM). The chemistry was analyzed with a Cameca Camebax electron microprobe (EMP). This instrument utilized $20 \mathrm{kv}$ and $10 \mathrm{nA}$ beam current. Compositions were determined using pure element calibration standards. The crystal structure was analyzed with a Philips transmission electron microscope (TEM).

\section{Results/Observations}

\section{IN792+Hf Wheels and Equiax/DS Blades}

Platelet phases relevant to the current work were observed in the hubs of equiax cast integral wheels and roots of aero turbine blades in the early 1980's $[15,16]$. The wheel hubs and roots were susceptible to segregation and slower cooling rates, both of which promoted formation of globular and platelet phases. The phases became apparent after $\mathrm{C}$ in the alloy was reduced from $-0.15 \mathrm{wt} \%$ to $\sim 0.08 \mathrm{wt} \%$. Examples of these phases are shown in Figures 1 and 2.

Fiedler [1], who described the phase from the standpoint of a turbine engine producer, was comfortable with $<5 \% \eta$ phase. It will be noted the amount of allowable $\eta$ phase remains at this level today. However, the method of measuring the phase is not simple, requiring $1 / 2 \mathrm{hr}$ or more of thermal tinting at $454 \mathrm{C}(850 \mathrm{~F})$. He mentioned there "was no apparent effect on conventional mechanical properties of primary concern was the potential to cause small surface cracks by abrasive machining practices."

More recently, platelet phases were found in a DS land base turbine blade made of IN792+ $\mathrm{Ht}$ as shown in Figure 3. The phase was within a crack-like void near the trailing edge (TE) and the platform. The "crack" was easily visible to the unaided eye, and affected several blades on the cluster.

The crack-like void formed parallel to the withdrawal direction, and platelets were seen to bridge the void. This led the author to conclude the platelets formed in the presence of a liquid. After the platelets formed, the liquid receded, leaving a gap. A brittle crack, which probably formed after the $1121 \mathrm{C}$ (2050F)/2 hr. solution heat treatment, is also seen to have severed some of the platelets. Despite this heat treatment, the platelet phases appeared to be stable. Adjacent to the platelets were recrystallized grains.

The compositions of the platelets in weight and atomic percentages, plus matrix, eutectic and other phases are shown in Table III. When compared to the average chemistry of the blade (determined by spectrographic methods), the platelet phases were shown to be enriched $10.5 \mathrm{X}$ in $\mathrm{Hf}$ and enriched $1.9 \mathrm{X}$ and $1.3 \mathrm{X}$ for $\mathrm{Ti}$ and $\mathrm{Ta}$, respectively. In the tables, " $\gamma$ elements" $\mathrm{Al}, \mathrm{Ti}, \mathrm{Ta}, \mathrm{HI}$, and Nb were summed below their listings, while " $y$ elements" Ni, $\mathrm{Co}, \mathrm{Cr}, \mathrm{Mo}, \mathrm{W}$, and $\mathrm{Fe}$ were summed above their listing. The $\gamma$ elements were also divided into the $\gamma$ elements so the reader can readily see ratios of phases in both weight and atomic percentages.

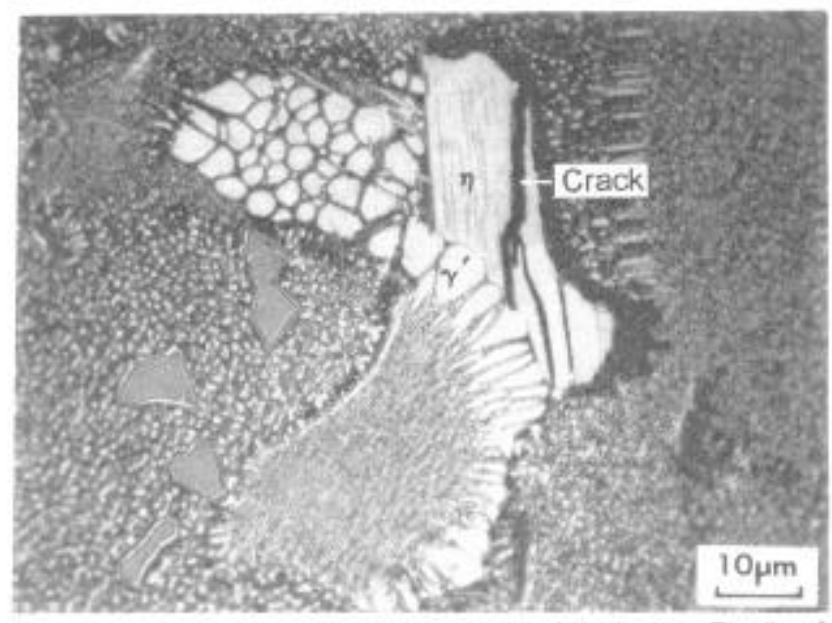

Figure 1. Platelet phases in a IN792+Hf blade. Fiedler [1] shows growth of $\eta$ from a $\gamma$ eutectic pool. Note the phase is also cracked. $10 \%$ Nitric electrolytic etch.

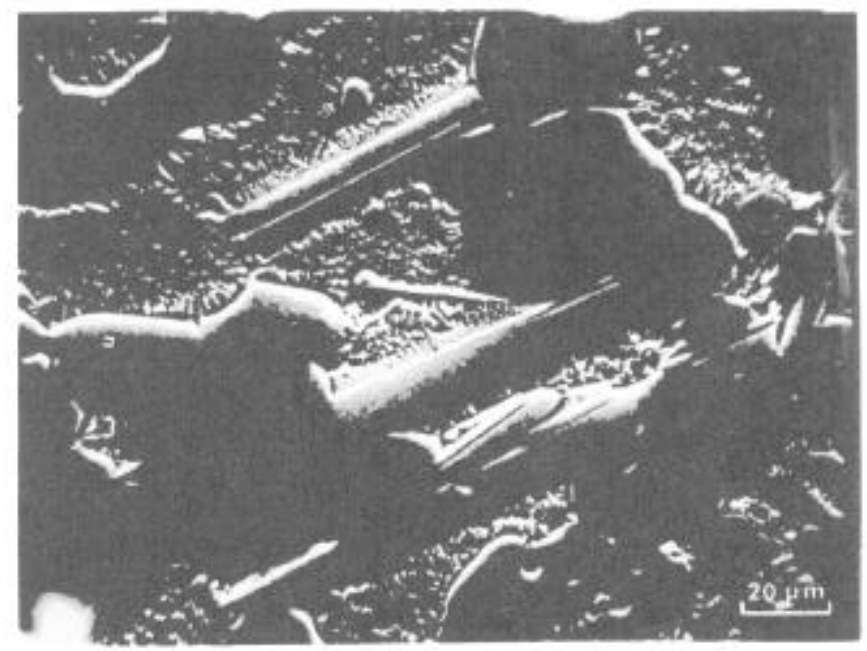

Figure 2. Emerson [15] shows an abundance of $\eta$ phase in both platelet and globular shapes in the hub of an $1 \mathrm{~N} 792+\mathrm{Hf}$ wheel. Oxalic acid etch.

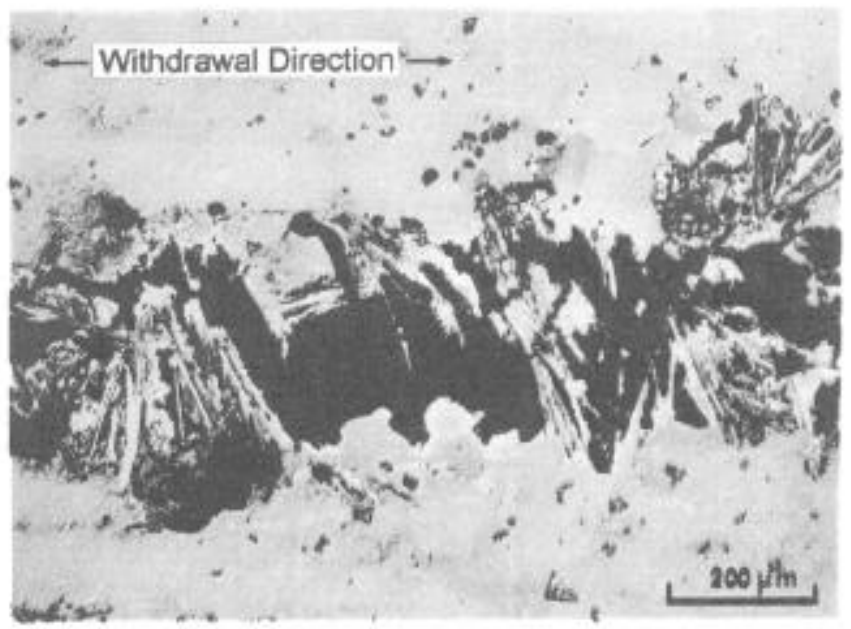

Figure 3. Platelet phases in the trailing edge of a DS IN792+ Hf turbine blade are seen to span a crack-like void. Recrystallized grains are also visible. Kallings etch. 
Table III, Average Corrpesitions of Phases in IN792+Het Alloy

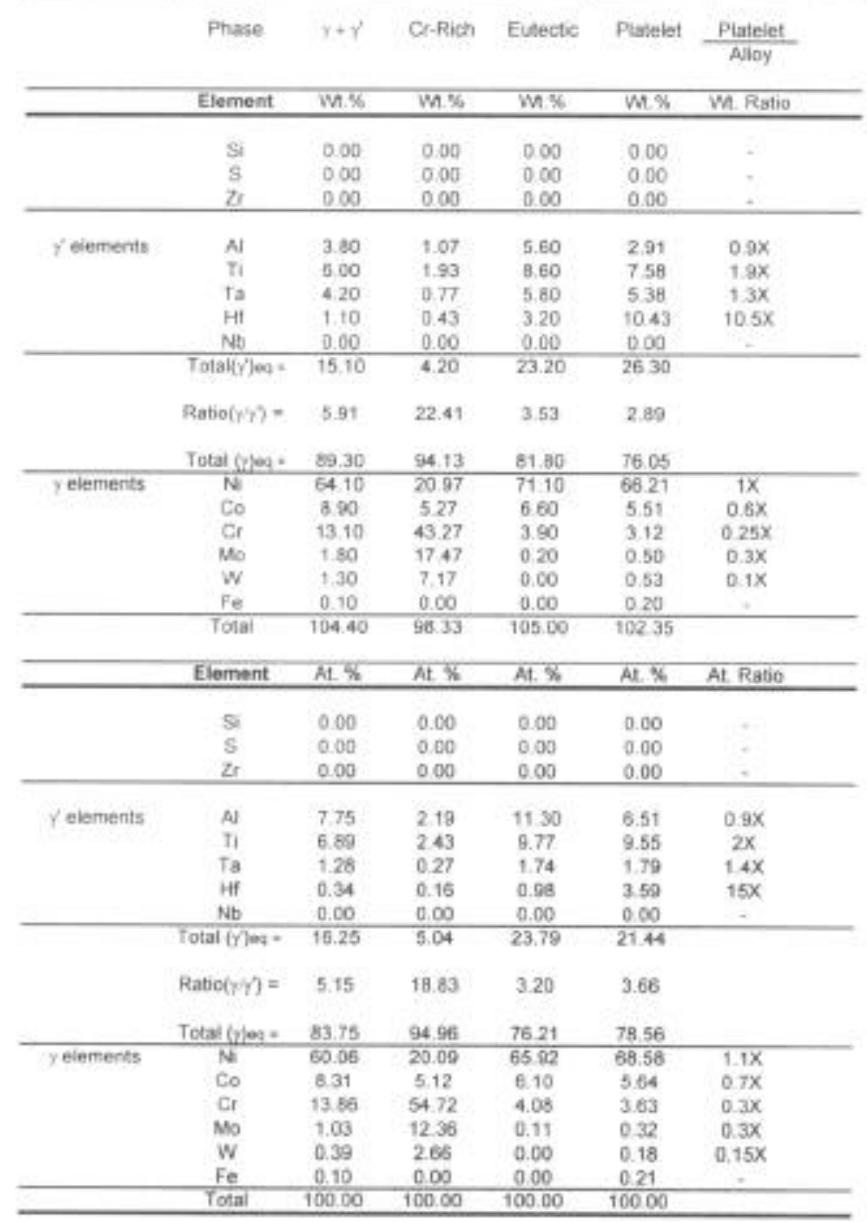

\section{IN6203 DS Blades}

A phenomenon similar to the $\mid \mathrm{N} 792+\mathrm{H} f$ blade platelet phases was found perpendicular to the withdrawal direction in IN6203 DS turbine blades, as shown in Figure 4. But for these blades, which are $38 \mathrm{~cm}$ (15 in.) long, the platelet phases were associated with a crack-like void and recrystallized grains, both of which presented difficulties during production.

Problems in casting turbine blades from this high-Cr DS alloy have been mentioned in the literature $[17,18]$, so considerable metallography was employed to find $\eta$-type phases during the casting process development [19]. It was tound that platelet phases were prone to form in the airfoil/platform fillet. Here, a disturbance in the solidification front may have occurred due to the change in section size.

In addition to the platelet phases, eutectic and "white" phases were characterized. All of the phases were Hi-rich. The compositions are shown in Table IV and were similar to platelet phases in the IN792+Hf parts discussed above. The $\mathrm{Hf}$ content of the IN6203 platelets was elevated $15.7 \mathrm{X}$ over the concentration of $\mathrm{Hf}$ in the alloy. Titanium, $\mathrm{Nb}$, and $\mathrm{Ta}$ were also elevated $2.8-1.3 \mathrm{X}$ over the alloy.
Table IV. Average Compositions of Phases in INE20s Alloy

\begin{tabular}{|c|c|c|c|c|c|c|}
\hline & Phase & $y+y^{\prime}$ & $\begin{array}{l}\text { White } \\
\text { Phase }\end{array}$ & Eutectic: & $\begin{array}{l}\text { Platelet } \\
\alpha \text { Giob }\end{array}$ & $\frac{\text { Platelet }}{\text { Aloy }}$ \\
\hline & Element & W. 8 & W. $\%$ & nt $x$ & m. 5 & Wi Ratio \\
\hline & 5 & 0.03 & 0.27 & Q.15 & 0.00 & - \\
\hline & $s$ & 0.00 & 0.00 & 0.00 & 0.00 & - \\
\hline & $2 \mathrm{r}$ & 0.00 & 4.07 & 2.04 & 0.47 & $-5 x$ \\
\hline \multirow[t]{8}{*}{$Y$ elements } & AL & 2.44 & 1.17 & 1.80 & 218 & $0.95 x$ \\
\hline & $\pi$ & 3.25 & 1.87 & 2.65 & 9.78 & $28 x$ \\
\hline & $\mathrm{Ta}$ & 0.94 & 0.17 & 0.55 & $1.4 t$ & $13 \mathrm{x}$ \\
\hline & Hit & 0.16 & 32.43 & 16.29 & 12.54 & $15.7 x$ \\
\hline & $\mathrm{Nb}$ & 0.51 & 1.63 & 1.07 & 1.47 & $18 x$ \\
\hline & Total $\left|\gamma^{\prime}\right| e=$ " & 7.30 & 37.27 & 22.28 & 2736 & \\
\hline & Ratio(x) $=$ & 12,70 & $1.5 \mathrm{a}$ & 3.40 & 2.65 & \\
\hline & Total loveg = & 9264 & 59.07 & 75.85 & 72.61 & \\
\hline \multirow[t]{11}{*}{ Tejernents } & $\mathrm{Ni}$ & 48.32 & 44.10 & 4621 & 59.76 & $1.3 x$ \\
\hline & $C_{0}$ & 19.67 & 12.03 & 15.85 & 10.11 & $0.5 x$ \\
\hline & $\mathrm{Cr}$ & 23.19 & 2.93 & 1306 & 2.70 & $0.1 x$ \\
\hline & Mo & 0.02 & 0.00 & 001 & 0.00 & 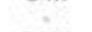 \\
\hline & w & 1.37 & 0.00 & 0.68 & 0.00 & $D 01 x$ \\
\hline & $\mathrm{Fe}$ & 0.09 & 0.00 & 0.04 & 0.04 & - \\
\hline & Tota & 99.97 & 100.67 & 10032 & 100.44 & \\
\hline & Element & At $x$ & A. $\%$ & AL. $\%$ & At. 5 & Al. Rateo \\
\hline & 5 & 0.06 & 0.71 & 0.38 & 0.00 & - \\
\hline & 5 & 0.00 & 0.00 & 0.00 & 0.01 & \\
\hline & $\mathrm{Zf}$ & 0.00 & 3.33 & 1.67 & 0.32 & $-5 x$ \\
\hline \multirow[t]{8}{*}{$\gamma$ einments } & $\mathrm{A}$ & 5.07 & 3.23 & 415 & 4.99 & $1 x$ \\
\hline & $\pi$ & 3.81 & 2.91 & 3.35 & 1252 & $3 \mathrm{x}$ \\
\hline & Ta & 0.29 & 0.07 & 0.18 & 0.48 & $1.4 x$ \\
\hline & $H$ & 0.05 & 13.57 & 6.81 & 4.33 & $173 x$ \\
\hline & No & 0.31 & 1.31 & 0.81 & 0.98 & $2 x$ \\
\hline & Yotal trlea & 8.53 & 21.60 & 15.31 & 2320 & \\
\hline & Ratio(x) = & 9.49 & 3.58 & 5.42 & 3.28 & \\
\hline & Totsl lypeg = & 90.46 & 75.58 & 8302 & 7638 & \\
\hline \multirow[t]{7}{*}{ y elements } & $\mathrm{Ni}$ & 46.18 & 56.11 & 51.15 & 6260 & $1.4 X$ \\
\hline & co & 18.73 & 15.25 & 16.09 & 10.55 & $0, x$ \\
\hline & $\mathrm{Cr}$ & 25.03 & 421 & 14.62 & 3.19 & $0.13 x$ \\
\hline & Mo & 0.01 & 0.00 & 0.00 & 0.00 & - \\
\hline & w & 0.42 & 0.00 & 0.21 & 0.00 & $0.01 x$ \\
\hline & $\mathrm{Fe}$ & 0.09 & 0.00 & 0.05 & 0.04 & - \\
\hline & Totil & 100.06 & 100.71 & 10038 & 100.00 & \\
\hline
\end{tabular}

In addition to the presence of these platelet phases, eutectics, voids, and recrystallized grains were found after heat treatment. In [17], it was noted the platelet phases were taken into solution at $>1600 \mathrm{C}(2912 \mathrm{~F})$. However, a temperature this high could not be used in production due to the incipient melting and grain growth that occurred. The platelets existed in both the as-cast and heat treated conditions. It was found that significant homogenization of these platelet phases did not occur during the solution cycle.

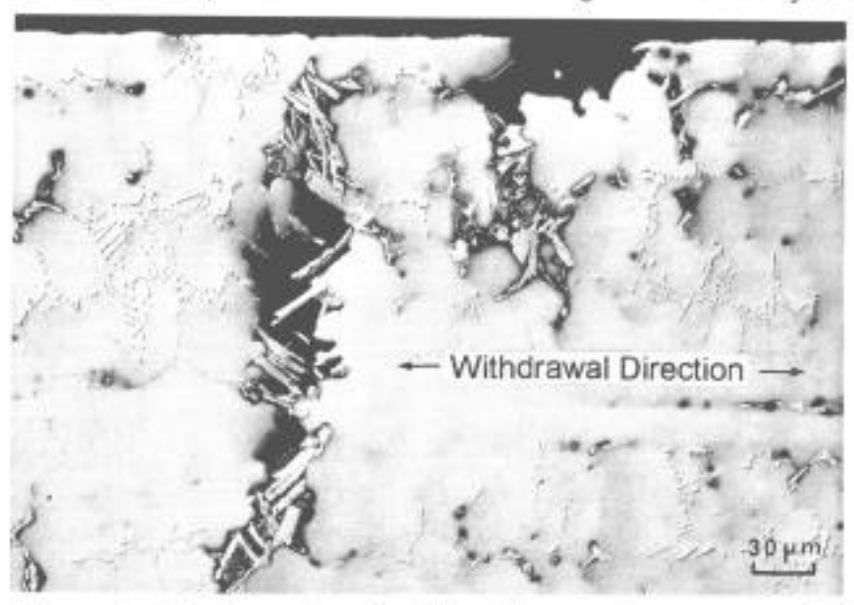

Figure 4. Photographs of platelet phases in an as-cast DS IN6203 blade. The platelet phase is seen to span a cracklike void that is perpendicular to the withdrawal direction. 


\section{INP39 Vane Segment}

IN939 is a well-studied alloy having a composition close to IN6203 but without Hf. Several characterizations have been performed on cast bars and slabs, and some references to $\eta$ phases with compositions similar to those discussed here have been mentioned [20-22]. Prevention of $\eta$ phases was accomplished mainly through homogenization at temperatures between 1145-1160C (2090-2120F) for 4 hrs.

An example of a platelet phase from an as-cast equiaxed IN939 land base vane segment is shown in Figure 5. Platelet phases in DS blades appear similar. After etching the metallographic mount, a cluster of the platelet phases became visible to the unaided eye. Upon closer examination, some of the platelet phase was cracked, but the matrix was not cracked. This would imply the phase was brittle, as it was not able to withstand the stresses of normal processing, which in this case only included casting. cleaning, wet radiac cutting, and metallographic polishing. Remnants of the platelet phases have also been observed after the standard $1160 \mathrm{C}(2120 \mathrm{~F}) / 4 \mathrm{hr}$ heat treatment, and may have been responsible for low tensile strength and ductility in test bars machined from another land-base nozzle segment that had no other apparent deficiencies [23].

The compositions of the platelet phases are given in Table V. The platelet phases were enriched by $3.7-1.8 \times$ for $\mathrm{Ti}, \mathrm{Nb}$, and $\mathrm{Ta}$. $\mathrm{A} \mathrm{Cr}$-rich phase was also encountered near the platelet phases.

Another similar alloy used for vane applications is GTD222 [3]. This alloy, however, does not form the platelet phases in the as-cast condition. A comparison of the critical elements for GTD222 in Table VI shows that $(\mathrm{Ti}+\mathrm{Ta}+\mathrm{Nb}) / \mathrm{Al}$ ratio is larger and the $\mathrm{C}$ content is less than for IN939, both of which might be expected to promote platelet phases. In this case the sum of the $\mathrm{Ti}+\mathrm{Ta}+\mathrm{Nb}$ is $2 \mathrm{wt} \%$ less for GTD222, which may be the limiting factor here.

Table V Comparison of C, Al, TI, Ta and $\mathrm{Nb}$ in IN939 \& GTD222

\begin{tabular}{|l|c|c|c|c|c|c|}
\cline { 2 - 7 } \multicolumn{1}{c|}{} & \multicolumn{6}{c|}{ Wi. \% of Elements } \\
\cline { 2 - 7 } \multicolumn{1}{c|}{} & $\mathrm{C}$ & $\mathrm{Al}$ & $\mathrm{TI}$ & $\mathrm{Ta}$ & $\mathrm{Nb}$ & $(\mathrm{Ti}+\mathrm{Ta}+\mathrm{Nb}) / \mathrm{Al}$ \\
\hline IN939 & 0.15 & 1.9 & 3.7 & 1.4 & 1 & $6.1 / 1.9=3.21$ \\
\hline GTD222 & 0.1 & 1.2 & 2.3 & 1 & 0.8 & $4.1 / 1.2=3.42$ \\
\hline
\end{tabular}

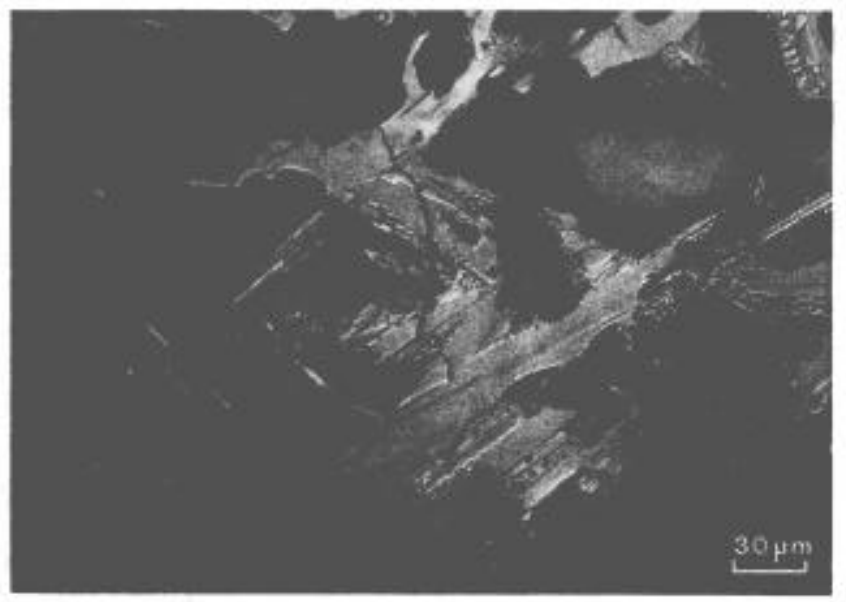

Figure 5. Cracked platelet phases in an as-cast equiax IN939 vane segment. Kallings etch.
Table V. Avorape Compoeitions of Phases in IN939 Alloy

\begin{tabular}{|c|c|c|c|c|c|}
\hline & Phase & $\gamma+\gamma$ & Cl-Rich & Pleielet & $\frac{\text { Platolot }}{\text { Alioy }}$ \\
\hline & Element & $m \%$ & $\mathrm{VA} \%$ & W. 8 & W. Ratio \\
\hline & Si & 0.00 & 0.00 & 0.00 & . \\
\hline & $\mathrm{s}$ & 0.00 & 0.00 & 0.00 & - \\
\hline & $\mathrm{Zr}$ & 0.08 & 0.00 & 0.02 & - \\
\hline \multirow[t]{8}{*}{$Y$ elements } & AI & 2.30 & 0.70 & 1.97 & $1 x$ \\
\hline & $\pi$ & 5.50 & 1.08 & 13.53 & $3.7 x$ \\
\hline & $\mathrm{Ta}$ & 1.33 & 0.08 & 2.53 & $1.8 x$ \\
\hline & Hf & 0.00 & 0.00 & 0.00 & . \\
\hline & $\mathrm{Nb}$ & 1.02 & 0.33 & 3.10 & $3.1 x$ \\
\hline & Total (r)ea" & 10.15 & 2.18 & 21.13 & \\
\hline & Ratio $\left.\left(y^{\prime}\right)^{2}\right)=$ & 8.76 & 45.33 & 3.73 & \\
\hline & Total $(y)$ eas. & 88.94 & 98.60 & 78.80 & \\
\hline \multirow[t]{11}{*}{$\gamma$ elemants } & N & 49.52 & 10.78 & 60.13 & $1.2 x$ \\
\hline & Co & 17.72 & 1390 & 13.80 & $0.7 x$ \\
\hline & $\mathrm{Cr}$ & 21.28 & 7235 & 4.85 & $0.2 x$ \\
\hline & Mo & 0.00 & 0.20 & 0.00 & $\therefore$ \\
\hline & $w$ & 0.36 & 1.33 & 0.11 & $0.08 x$ \\
\hline & $\mathrm{Fe}$ & 0.06 & 0.05 & 0.00 &. \\
\hline & Total & 98.17 & 100.78 & 99.95 & \\
\hline & Element & MI \% & At $x$ & AL. $\%$ & At Ranto \\
\hline & $\mathrm{Si}$ & 0.00 & 0.00 & 0.00 & - \\
\hline & $s$ & 0.00 & 0.00 & 0.00 & - \\
\hline & $\mathrm{zr}$ & 0.05 & 0.00 & 0.01 & $=$ \\
\hline \multirow[t]{8}{*}{$\gamma^{\prime}$ elements } & A & 4.30 & 1.38 & 4.18 & $1 x$ \\
\hline & $\mathrm{Ti}$ & 6.47 & 1.20 & 18.10 & $3.7 x$ \\
\hline & Ta & 0.41 & 0.02 & 0.00 & $1.8 x$ \\
\hline & $\mathrm{HF}$ & 0.00 & 0.00 & 0.00 & - \\
\hline & $\mathrm{Nb}$ & 0.52 & 0.10 & 1.90 & $32 x$ \\
\hline & Total (6)ea" & 12.30 & 2.79 & 22.08 & \\
\hline & Ratio $(n+y)=$ & 7.13 & 34.82 & 3.38 & \\
\hline & Total (y)e. & 87.88 & 97.21 & 77.03 & \\
\hline \multirow[t]{7}{*}{$y$ eioments } & NI & 47.50 & 0.80 & 56.43 & $1.3 x$ \\
\hline & $C_{0}$ & 16.83 & 1250 & 13.46 & $0.7 x$ \\
\hline & Cr & 23.06 & 74.28 & 5.11 & $0.2 x$ \\
\hline & Mo & 0.00 & 0.11 & 0.00 & $\therefore$ \\
\hline & w & 0.11 & 0.38 & 0.03 & $0.05 x$ \\
\hline & $\mathrm{Fe}_{\mathrm{E}}$ & 0.08 & 0.05 & 0.00 &. \\
\hline & Total & 10000 & 100.00 & 100.00 & \\
\hline
\end{tabular}

\section{GTD111 DS Turbine Blades}

Both types of platelet phases have been found in GTD111 turbine blades $[24,25]$. Examples of these morphologies are shown in Figures 6 and 7 . Both examples of the platelets were associated with cracks that were open to the external surfaces of the blades, which were subsequently detected by FPI. Figure 6 shows the coarse platelet phase in the ascast condition, while Figure 7 shows the fine platelets after the $1121 \mathrm{C}(2050 \mathrm{~F}) / 2 \mathrm{hr}$. solution heat treatment.

In Figure 6, the coarse platelets were shown to span a crack-like void. In order for this to have happened, it is hypothesized the platelets formed from the liquid, which then receded to another location, leaving a void. Also, note the absence of eutectic. The compositions of the platelets are given in Table VII. The platelets were enriched 2.6X and 2.1X in Ti and Ta, respectively.

In the absence of cracking, the platelet phase most often seen in the GTD111 alloy is shown in Figure 7. These fine platelets, which in this case were associated with an interdendritic crack, may often be missed because the platelets are small and intimate with the $\gamma$ eutectic pools. To the untrained eye these fine platelets may resemble metallographic polishing artifacts. As such, it is difficult to measure quantities of fine platelet phases. The composition 
Table VI. Average Compositions of Phases in GTD111 Alloy

\begin{tabular}{|c|c|c|c|c|c|c|}
\hline & Phase & $\gamma+\gamma^{\prime}$ & $\begin{array}{l}\text { Bright } \\
\text { Phase }\end{array}$ & Eutectic & Platelet & $\frac{\text { Platelet }}{\text { Alloy }}$ \\
\hline & Element & W. \% & Wt. \% & Wt. \% & Wt. \% & W. Ratio \\
\hline & Si & 0.00 & 0.05 & 0.00 & 0.02 & $-2 x$ \\
\hline & s & 0.00 & 0.00 & 0.00 & 0.00 & - \\
\hline & $\mathrm{Zr}$ & 0.00 & 0.00 & 0.00 & 0.00 & - \\
\hline \multirow{8}{*}{$\gamma^{\prime}$ elements } & Al & 3.41 & 2.05 & 4.12 & 3.24 & $1.1 \mathrm{x}$ \\
\hline & Ii & 4.25 & 4.30 & 7.67 & 11.30 & $2.3 x$ \\
\hline & $\mathrm{Ta}$ & 1.50 & 1.65 & 1.80 & 4.28 & $1.5 \mathrm{X}$ \\
\hline & $\mathrm{Hf}$ & 0.00 & 0.05 & 0.00 & 0.00 & - \\
\hline & $\mathrm{Nb}$ & 0.00 & 0.00 & 0.00 & 0.02 & - \\
\hline & Total $\left(\gamma^{\prime}\right)$ eq $=$ & 9.16 & 8.05 & 13.59 & 18.83 & \\
\hline & $\operatorname{Ratio}\left(\gamma / \gamma^{\prime}\right)=$ & 9.82 & 11.34 & 6.36 & 4.22 & \\
\hline & Total $\{\gamma)_{\text {eq }}=$ & 89.91 & 91.25 & 86.41 & 79.45 & \\
\hline \multirow[t]{11}{*}{$y^{\prime}$ elements } & $\mathrm{Ni}$ & 60.26 & 53.90 & 64.27 & 68.01 & $1.1 \mathrm{X}$ \\
\hline & Co & 10.05 & 10.30 & 8.86 & 6.67 & $0.7 x$ \\
\hline & $\mathrm{Cr}$ & 16.18 & 21.80 & 12.16 & 4.11 & $0.3 x$ \\
\hline & Mo & 1.40 & 3.05 & 1.02 & 0.54 & $0.4 x$ \\
\hline & W & 2.00 & 2.20 & 0.11 & 0.10 & $0.02 x$ \\
\hline & $\mathrm{Fe}$ & 0.03 & 0.00 & 0.00 & 0.00 & - \\
\hline & Total & 99.07 & 99.35 & 100.00 & 98.30 & \\
\hline & Eloment & At: $\%$ & At $\%$ & At \% & At Pct: & At Ratío \\
\hline & Si & 0.00 & 0.10 & 0.00 & 0.04 & $-2 x$ \\
\hline & s & 0.00 & 0.00 & 0.00 & 0.00 & - \\
\hline & $\mathrm{Zr}$ & 0.00 & 000 & 0.00 & 0.00 & $\div$ \\
\hline \multirow{8}{*}{$\gamma^{\prime}$ elements } & Al & 7.19 & 4.38 & 8.42 & 6.84 & $1.15 x$ \\
\hline & Ti & 5.05 & 518 & 8.83 & 1362 & $24 x$ \\
\hline & Ta & 0.48 & 0.53 & 0.55 & 1.38 & $17 x$ \\
\hline & $\mathrm{H}$ & 000 & 0.02 & 0.00 & 0.00 & - \\
\hline & $\mathrm{Nb}$ & 0.00 & 0.00 & 0.00 & 0.01 & - \\
\hline & Total $(\gamma) e q=$ & 1273 & 1011 & 17.80 & 2186 & \\
\hline & Ratio $(y / y)=$ & 6.86 & 8.88 & 4.62 & 3.58 & \\
\hline & Total $(y)$ eg $=$ & 87.27 & 89.79 & 82.20 & 78.14 & 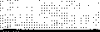 \\
\hline \multirow[t]{7}{*}{$\gamma$ elements } & Ni & 58.43 & 6208 & 60.38 & 66.76 & $11 \mathrm{X}=$ \\
\hline & Co & 9.70 & 10.08 & 8.29 & 6.52 & $0.75 x$ \\
\hline & $\mathrm{Cr}$ & 17.67 & 24.20 & 12.91 & 4.52 & $0,3 x$ \\
\hline & Mo & 0.83 & 184 & 0.59 & 0,33 & $0,4 x$ \\
\hline & $w$ & 0.63 & 069 & 0.03 & 0,03 & $0.03 X$ \\
\hline & $\mathrm{Fe}$ & 0.03 & 0.00 & 0.00 & 000 & 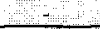 \\
\hline & Total & 100.00 & 100.00 & 10000 & 10004 & \\
\hline
\end{tabular}

of these platelets could not be reasonably distinguished from the composition of the eutectic.

The mechanical properties for a wide range of land-base turbine blades made from GTD111 alloy were reviewed. These were reviewed because of potential concern for increasing amounts of platelet phases due to casting segregation or slower cooling rates due to increased size of the blades. It was found that there was no noticeable downward trend in properties. In a separate study performed at GE [26], where $\mathrm{Ti}$ and $\mathrm{Ta}$ were both at the high limits of the specification, there was no measurable effects of the

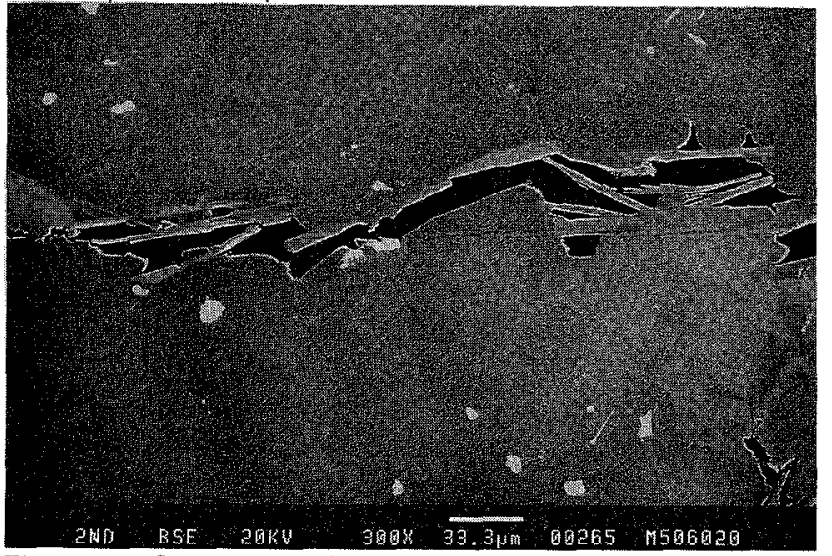

Figure 6. Coarse platelets spanning a crack-like void in an as-cast DS GTD111 turbine blade. Kallings etch. platelet phases. These studies suggests that small amounts of platelets may not be deleterious to mechanical properties.

\section{C103 SC Turbine Blade}

This alloy is a derivative of IN792-type alloys used for single crystal turbine blade applications. Other alloys such as SX792, AF56, and PWA1483 are similar to C103, so the platelet phases described for this alloy might be found in the other alloys if processed similarly.

In this case, the platelets were found in the as-cast condition, and manifested themselves as scale on the airfoil near the platform. Usually this would not be a problem, because scale can be removed after heat treat. However, in this case, recrystallized grains were found with the scale after heat treatment. When metallographic sections were made through the airfoil, platelets like those shown in Figure 8 were found. These platelets were on the surface of the blade, and extended to a depth of about $0.1 \mathrm{~mm}(0.005 \mathrm{in}$.). The composition of the platelets is given in Table VIII.

The platelets were enriched by $2.6-2.1 \mathrm{X}$ in $\mathrm{Ti}$ and $\mathrm{Ta}$, respectively, over the amounts found in the alloy. In addition

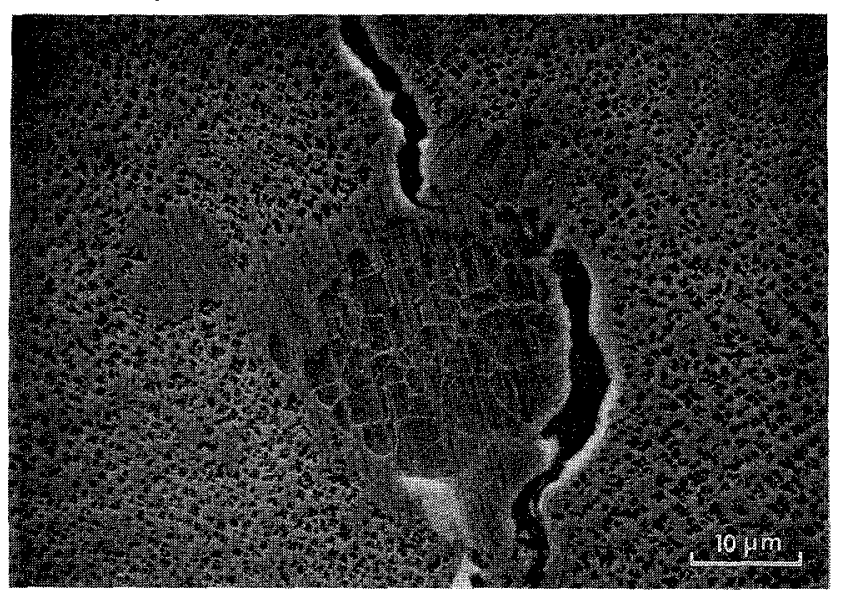

Figure 7. Fine platelet phases within a $\gamma$ eutectic pool, next to a crack in a DS GTD111 turbine blade that was given the solution heat treatment. Kallings etch.

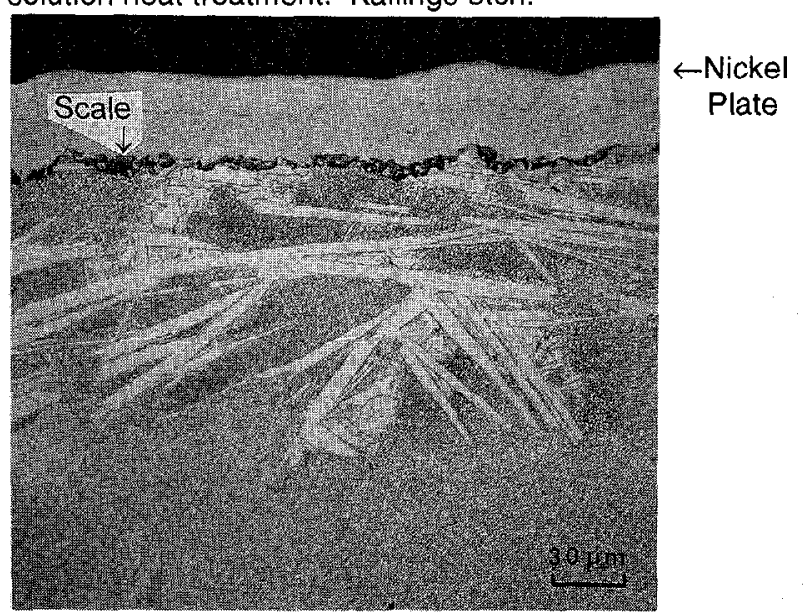

Figure 8. Platelet phases in an as-cast $\mathrm{SC} \mathrm{C}_{103}$ turbine blade. From the casting surface, "scale" is seen to cover the platelets. Kallings etch. 
Table VILl Average Compositions of Phases in C103 Alloy.

\begin{tabular}{|c|c|c|c|c|c|}
\hline & & $\begin{array}{l}\text { Whine } \\
\text { (sirchi) }\end{array}$ & Dark & Platelet & $\frac{\text { Platelel }}{\text { Alloy }}$ \\
\hline & Elemert: & W. $\%$ & M. $\%$ & W 5 & Wh. Falis \\
\hline & Si & 5.88 & 0.34 & 0.05 & $-5 x$ \\
\hline & 5 & 0.00 & 0.00 & 0.00 & . \\
\hline & $\mathrm{Zr}$ & 0.00 & 0.02 & 0.01 & - \\
\hline \multirow[t]{8}{*}{$Y$ eiements } & AI & 0.26 & 4.98 & 3.30 & $0.95 x$ \\
\hline & Ti & 488 & 11.00 & 10.84 & $2.6 x$ \\
\hline & Ta & 1065 & 4.61 & 10.41 & $2.1 \mathrm{x}$ \\
\hline & $\mathrm{Hf}$ & 0.00 & 0 do & 0.00 & - \\
\hline & $\mathrm{Nb}$ & 0.00 & 0.00 & $D, 00$ & - \\
\hline & Total frleg $=$ & 15.79 & 20.59 & 24.64 & \\
\hline & Ratio fry'beq = & 4.99 & 3.91 & 307 & \\
\hline & Total tyeq = & 78.77 & BD so & 75.65 & \\
\hline \multirow[t]{11}{*}{ relements } & $N$ & 26.17 & 6969 & 65.10 & $1.1 x$ \\
\hline & $\mathrm{Co}$ & 1160 & 7.04 & B.85 & $0.8 x$ \\
\hline & $\mathrm{Cr}$ & 16.63 & 351 & 3.17 & $0.3 x$ \\
\hline & Mo & 17.87 & 026 & 0.45 & $0.26 x$ \\
\hline & $w$ & 6.30 & 000 & 0.09 & $002 x$ \\
\hline & $\mathrm{Fe}$ & 000 & 0.00 & 000 & . \\
\hline & Total & 10044 & 101.45 & 10038 & \\
\hline & Bement & A. Pd & AL.PA. & Ac. Pct. & At. Fatso \\
\hline & $S$ & 13.36 & 0.57 & 0.10 & $-5 x$ \\
\hline & $s$ & 0.00 & 0.00 & 0.00 & \\
\hline & $\mathrm{Z}$ & 0.00 & 0.01 & 0.01 & - \\
\hline \multirow[t]{8}{*}{$f$ eiements } & $\mathrm{Al}$ & 0.62 & 10.16 & 7.39 & $0.93 x$ \\
\hline & 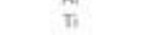 & 6.50 & 12.64 & 13.30 & $2.8 x$ \\
\hline & $\mathrm{Ta}_{\mathrm{s}}$ & 3.76 & 1.40 & 338 & $2.1 x$ \\
\hline & Hif & 0.00 & 0.00 & 0.00 & - \\
\hline & $\mathrm{Nb}$ & 0.00 & 0,00 & 000 & - \\
\hline & Tolal $(2) e q=$ & 10.88 & 24.20 & 24.07 & \\
\hline & Rano (rv)ec = & 697 & 3.13 & 3.15 & \\
\hline & Total (n)eq = & 75.76 & 75.78 & 75.92 & \\
\hline \multirow[t]{7}{*}{ revements } & $\mathrm{Ni}$ & 28.46 & 65.34 & 65.18 & $1.1 \times$ \\
\hline & $\mathrm{Co}$ & 12.57 & 6.58 & 0.84 & $0.70 x$ \\
\hline & $\mathrm{Cr}$ & 20.66 & 3.72 & 3.58 & $0.26 x$ \\
\hline & Mo & 11.89 & 0.15 & 0.28 & $0.26 x$ \\
\hline & w & 2.19 & 0.00 & 0.03 & $0.03 x$ \\
\hline & Fo & 0.00 & 0.00 & 0.00 & - \\
\hline & Total & 100.00 & 100.67 & 100.10 & \\
\hline
\end{tabular}

the Si was enriched several times, which undoubtedly is due to a contribution by the investment shell.

Two other phases contributed by the reactions with the shell were also found near the platelet phases. These phases, termed "white" and "dark," are listed in Table VIII, and contained up to $-6 \mathrm{wt}$. $\% \mathrm{Si}$ in the "white" phase. This phase was also rich in $\mathrm{Mo}, \mathrm{Cr}, \mathrm{Co}$, and $\mathrm{Ta}$.

\section{Low Carbon PWA1480 SC Turbine Blades}

Low carbon versions of normal PWA1480 are used for noncommercial aerospace applications, so the presence of carbides could be eliminated as a source of fatigue cracks. Normal PWA1480 with about $0.04 \%$ carbon is not susceptible to the formation of platelet phases. However, when $\mathrm{C}$ is reduced to $<0.01 \mathrm{wt} \%$, platelet phases may form on the surfaces adjacent to the investment shell or core.

The presence of the platelet phases was discovered below a layer of scale that was present on the turbine blades in the as-cast condition. The scale could not be easily removed. These platelet phases, shown in Figure 9, formed adjacent to the zircon facecoat of the investment shell. The compositions of the platelet phases are given in Table IX, and show $\sim 2 \mathrm{X}$ increases in $\mathrm{Ti}$ and $\mathrm{Ta}$ over the base alloy. Silicon was also found to have increased several times over normal, undoubtedly due to reactions with the shell. In addi-
Table IX. Average Compositions of Phases in Low Garbon PWA14b0 Altoy

\begin{tabular}{|c|c|c|c|c|c|c|c|c|}
\hline & & $y+y$ & Dark & White & $\begin{array}{l}\text { Phatelet } \\
\text { (Core } \\
\text { Side) }\end{array}$ & $\begin{array}{l}\text { Pisleiet } \\
\text { (Shel } \\
\text { Sibe) }\end{array}$ & $\begin{array}{l}\text { Platelet } \\
\text { (Oresail) }\end{array}$ & $\frac{\text { Pialeiel }}{\text { Aliby }}$ \\
\hline & Element & 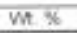 & $m \&$ & W. Pat & $m \times$ & $\mathrm{M} \%$ & W. 8 & W. Raito \\
\hline & p & 0.00 & -200 & 000 & 0.00 & 0.00 & 0.00 & - \\
\hline & 5 & 0.00 & 0.00 & 0.60 & 0.08 & 0.03 & 0.06 & $-\alpha$ \\
\hline & 5 & 0.00 & 0.10 & 0.00 & 0.60 & 000 & 0.00 & \\
\hline & $\mathrm{Zr}_{r}$ & 0.00 & $0, \infty$ & 000 & 0.00 & 0.00 & 0.01 & $-1 x$ \\
\hline \multirow[t]{8}{*}{$Y^{\prime}$ elements } & A & 5.05 & 0.18 & D. 80 & 3.48 & 3.70 & 3.57 & $07 x$ \\
\hline & $\pi$ & 1.50 & 433 & 1.25 & 208 & 4.30 & 3.03 & $2 x$ \\
\hline & Ta & 11.20 & 6.55 & 35.85 & 2468 & 24.77 & 24.71 & $2.1 x$ \\
\hline & Hif & 0.00 & 0.00 & 000 & 0.00 & 0.00 & 0.00 & \\
\hline & Ne & 0.00 & 0.00 & 000 & 000 & 0.00 & 0.00 & - \\
\hline & Total (f) & 17.75 & 11.06 & 3790 & 30.23 & 32.77 & 31.31 & \\
\hline & Fate $\left(y y^{\prime}\right)=$ & 4.59 & 6.22 & 161 & 2.31 & 202 & 2.18 & \\
\hline & Total cyleq $=$ & 8145 & 68.82 & 61.20 & 69.78 & 68.69 & 68.17 & \\
\hline \multirow[t]{12}{*}{$y$ eiernents } & N & 62,15 & 36.25 & 26.10 & 60.33 & 97.60 & 59.16 & $0.0 x$ \\
\hline & Co & 5.40 & 702 & 590 & 4.10 & 4.43 & 4.24 & $0.85 x$ \\
\hline & $\mathrm{Cr}$ & 1080 & 2550 & 17.30 & 3.73 & 400 & 3.84 & $0.4 x$ \\
\hline & Mo & 0.00 & 000 & 0.00 & 0.08 & 000 & 0.04 & . \\
\hline & w & 3.10 & 0.00 & 11.00 & 150 & 0.00 & 0.86 & $02 x$ \\
\hline & $\mathrm{Fe}$ & 0.00 & 0.05 & 0.00 & 0.05 & 0.00 & 0.03 & - \\
\hline & Total & 99.20 & 99.80 & 99.70 & 190.10 & 9683 & 99.56 & \\
\hline & Element & At. $\%$ & AL $\%$ & AL PG. & At. $\%$ & At $\mathrm{X}$ & At $x$ & A. Rajo \\
\hline & P & $0 \% 0$ & 32.12 & & 0.00 & 000 & 0.00 & 7 \\
\hline & 5. & 0,00 & 0.00 & 178 & 018 & 008 & 0.14 & $-b x$ \\
\hline & 5 & 0.00 & 0.16 & 0.00 & 0.00 & 0.00 & 0.00 & \\
\hline & $2 t$ & 0.90 & 0.00 & 0.00 & 0.02 & 0.00 & 0.09 & $-1 x$ \\
\hline \multirow{8}{*}{ ' esersents } & Al & $11: 31$ & 0.32 & 2.44 & 8.66 & 9.17 & 8.88 & $0.63 x$ \\
\hline & Ti & 1.89 & 4.50 & 2.16 & 2.91 & 5.99 & 4.23 & $2.6 x$ \\
\hline & $\mathrm{Ta}$ & 374 & 1.80 & 16.65 & 9.17 & 815 & 9. 16 & $2.3 x$ \\
\hline & it & 0.00 & 0.00 & 0.00 & 0.00 & 0.00 & $0 . \infty$ & + \\
\hline & No & 000 & 0.00 & 0.00 & 0.00 & 0.00 & 0.00 & - \\
\hline & Total fyleq : & 16.94 & 6.82 & 21.25 & 20.74 & 24.31 & 22.27 & \\
\hline & Ratio(wn) $=$ & 4.90 & 9.23 & 3.71 & 3.82 & 311 & 3.40 & \\
\hline & Total trieg: & 8306 & 610 & 78.75 & 7924 & 75.69 & $n n$ & \\
\hline \multirow[t]{7}{*}{ reiements } & $\mathrm{Ni}$ & 63.96 & 30.72 & 36.52 & 60.06 & 68.51 & 67.55 & $1 x$ \\
\hline & $\mathrm{Co}_{0}$ & 5.54 & 5.93 & 8.40 & 4.68 & 5.03 & 4.80 & $1 x$ \\
\hline & a & 12.55 & 24.40 & 28.00 & 4.82 & 5.15 & 4.96 & $0.5 x$ \\
\hline & Mo & 0.00 & 0.00 & 0.00 & 0.05 & 000 & 0.00 & \\
\hline & w & 1.02 & 0.00 & 5.44 & 0.55 & 0.00 & 0.31 & $0.25 x$ \\
\hline & $\mathrm{Fe}$ & 0.00 & 0.04 & 0.00 & 0.06 & 000 & 0.00 & - \\
\hline & Total & 10000 & 9990 & 104.78 & 100.18 & 100.00 & 100.14 & \\
\hline
\end{tabular}

tion to the platelet phases, a white eutectic phase also formed which contained almost $\sim 36 \mathrm{wt} . \% \mathrm{Ta}$.

Utilization of microdiffraction techniques by [13] revealed the platelets consisted of two phases. The continuous phase visible with metallography was an orthorhombic phase, identified as $\mathrm{Ni}_{3} \mathrm{Ta}$. Aligned precipitates within the $\mathrm{Ni}_{3} \mathrm{Ta}$ phase had a hexagonal structure and were identified as $\mathrm{Ni}_{3} \mathrm{Ti}$ or $\eta$ phase, as shown in Figure 10.

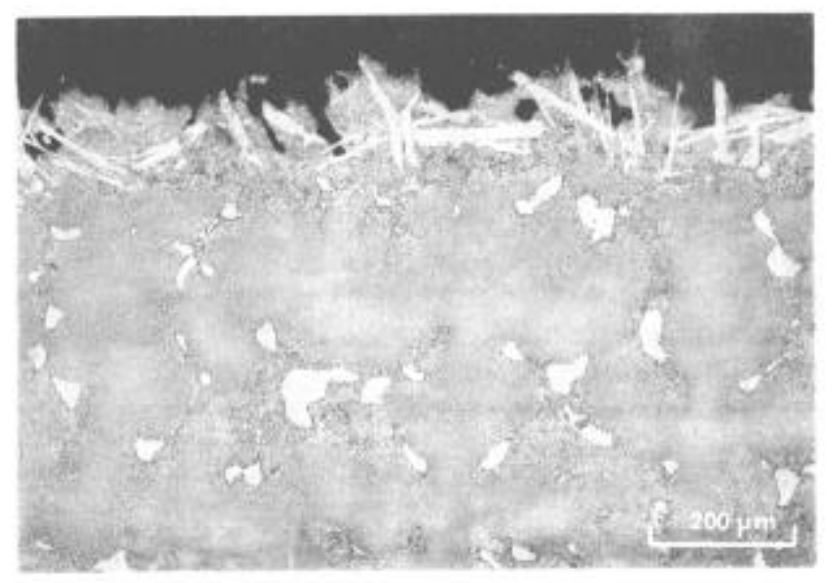

Figure 9. Platelet phases on the external surfaces of a low carbon PWA 1480 turbine blade [13]. Nitric electrolytic etch. 
In other turbine blades, using an improved tacecoat, platelets were found adjacent to some internal (core) surfaces [27]. An example of this platelet is shown in Figure 11. In this case, the silica-zircon core reacted with the alloy, and platelets were produced, differing only in $\mathrm{Ti}$ and $\mathrm{W}$ content from the platelets discussed above. In addition, a "dark" phase, as described in Table IX, was adjacent to the platelet phase. This phase contained about $20 \mathrm{wt} \% \mathrm{P}$. which probably came from inadequate rinsing after being grain etched with $\mathrm{H}_{3} \mathrm{PO}_{4}$ acid, and then being given the full solution heat treatment. The presence of the $\mathrm{H}_{3} \mathrm{PO}_{4}$ acid probably contributed to the formation of the platelets.

\section{Discussion}

There may be some confusion about what the industry has traditionally termed $\eta$ phase, and what recent Howmet researchers have presented. We know that $\eta$ phase is $\mathrm{HCP}$. and has solubility for several elements. Another phase that can take on the platelet appearance of $\eta$, identified as $\delta$ or $\mathrm{Ni}_{3} \mathrm{Ta}$, has an orthorhombic structure. This phase also has solubility for several elements. Both of these phases can coexist, with $\mathrm{Ni}_{3} \mathrm{Ti} \eta$ precipitates being completely soluble within the $\mathrm{Ni}_{3} \mathrm{Ta}$ orthorhombic phase, Based on Figure 10, it would appear the precipitates are aligned in the long direction of the platelet.

\section{Effect of Maior Alloying Elements on the Formation of Platelet Phases}

When the compositions of the platelet are divided by the amount of element in the base alloy, the segregation for each element can be expressed in terms of a multiplication factor. These factors for several of the alloying elements that

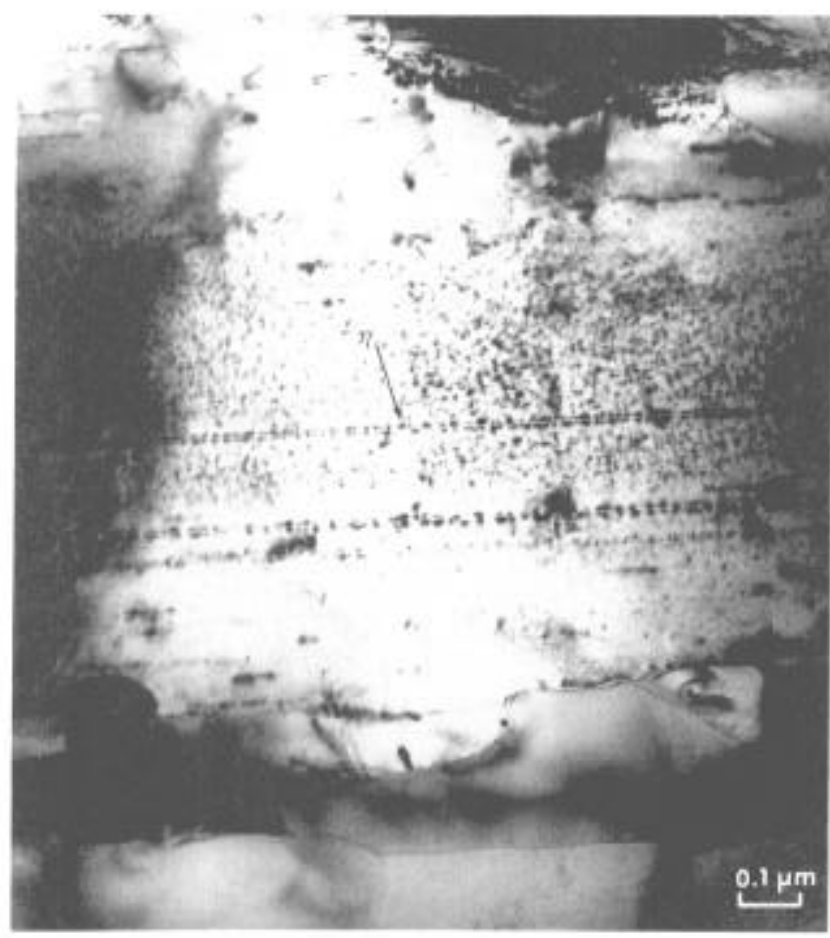

Figure 10. Brightfield image of an orthorhombic platelet phase as shown in Figure 9. Within the orthorhombic phase were alianed precipitates of hexaconal $n$ phase [13]. contribute precipitate strengthening are:

- hafnium, 10-15X (up to 15 times the amount in base alloy)

- titanium, 1.9-3.7X

- niobium, 1.8-3.1X

- tantalum, 1.3-2.1X

While it may not be possible to lower these elements without causing a loss of mechanical strength or corrosion resistance, there may be a trade-off between producibility and optimizing microstructures at all locations in large parts.

Aluminum and nickel are fairly neutral in partitioning to the platelet phases, with multiplication factors of $0.7-1.1 \mathrm{X}$, and $0.9-1.3 X$, respectively. For those remaining elements that contribute solid solution strengthening, four were rejected from the platelets. Their multiplication factors were:

- cobalt, $0.5-0.85 \mathrm{X}$

- molybdenum, 0.2-0.4X

- chromium, 0.1-0.4X

- tungsten, $-0.1 X$ (almost totally rejected)

\section{Effect of Carbon on the Formation of Platelet Phases}

Carbon, which is tightly controlled during alloy-making, has a great influence on forming platelet phases. When $\mathrm{C}$ is reduced from $0.04 \mathrm{wt} . \%$ to $<0.01 \mathrm{wt} \%$ in PWA1480 in the presence of ceramic cores and shells from the investment casting process, platelet phases formed. When carbon was reduced from 0.15 wt. $\%$ to 0.08 wt. $\%$ in an alloy like IN $792+\mathrm{Hf}$, the formation of platelet phases was promoted, especially for castings subject to segregation in thick sections or to slow solidification rates.

The traditional argument has been that carbon "ties-up" the platelet-forming elements. Thus, when carbon is removed from the alloy, more of platelet-forming elements are free to form the platelet phases. If this were the only mechanism, it becomes difficuit to understand why so many platelet phases are created in PWA1480 after releasing only an additional $300 \mathrm{ppm}$ carbon, when the $\mathrm{Ta}+\mathrm{Ti}$ levels are already near $13.5 \mathrm{wt} . \%$

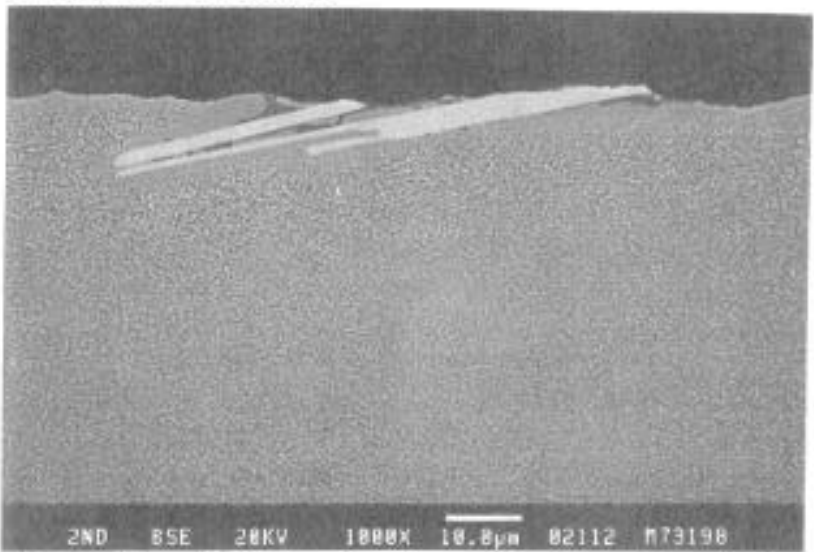

Figure 11. Platelets found next to the internal (core) surfaces on a solution heat treated SC PWA1480LC turbine blade. The dark phase contains $P$, probably from inadequate rinsing atter the $\mathrm{H}_{3} \mathrm{PO}_{4}$ grain etch cycle. Kallings etch. 
Effect of Minor/Trace Elements on the Formation of Platelet Phases

Even though the platelets were not found to contain high amounts of $\mathrm{Si}, \mathrm{Zr}$, or $\mathrm{P}$, it is apparent they formed in the presence of enriched "white" or "dark" phases, which contained significant amounts of $\mathrm{Si}, \mathrm{Zr}$, and $\mathrm{P}$. As suggested by [14], the amount of these phases could be reduced by lowering $\mathrm{Si}, \mathrm{Zr}$, and $\mathrm{P}$. This, however, will not be easy, as investment shells and cores are full of $\mathrm{SiO}_{2}, \mathrm{Zr}_{2} \mathrm{SiO}_{4}$ and $\mathrm{ZrO}_{2}$, which eventually break down, especially for DS and SC castings [28]. This problem is intensified for the larger landbase castings, where liquid alloy may be in contact with the shells and cores for an hour or more. The $P$ has the most likely chance of being reduced by proper rinsing of parts after $\mathrm{H}_{3} \mathrm{PO}_{4}$ acid etching or after use of FPI fluids which also contain P.

\section{Summary}

Based upon the results of this study, most of the platelet phases are believed to have formed due to:

- growth from $\gamma$ eutectic pools,

- casting segregation, and

- reactions with the investment shell and/or core.

Both coarse and fine platelet structures were observed. Coarse platelets were most often observed in the as-cast condition. After solution heat treatment, the shape of these platelets underwent little change. The presence of coarse platelets was usually associated with a crack-like void, scale, or recrystallized grains. Thus, these types of platelet phases were found by visual examination, grain etch, FPI, or x-ray inspection. The fine platelets were usually associated with $\gamma$ eutectic pools. These fine platelets were found in both the as-cast and fully heat treated condition. They were also associated with cracks that were found by FPI methods.

The concern for the presence of these platelet phases should be in the least inspectible areas of the parts, which have traditionally been on internal surfaces, where current cleaning methods may not adequately remove such phases. While small amounts of the platelet phases may not have caused noticeable losses of mechanical properties to date, it would be prudent to monitor the amount of the platelet phases as the parts become larger, or if the DS/SC casting process becomes longer.

\section{Conclusions}

1. Platelet phases were characterized in equiax IN939, equiax and DS IN792+Hf, DS IN6203 and GTD111, SC C103, and in low carbon versions of SC PWA1480.

2. The platelet phases are generally known to consist of $\mathrm{Ni}_{3} \mathrm{Ti}(\eta)$ eta phase (which has an HCP structure), and$\mathrm{Ni}_{3} \mathrm{Ta}(\delta)$ delta phase (which has an orthorhombic structure).

3. The platelet phases generally had $10-15 \mathrm{X}$ the concentration in the alloy for $\mathrm{Hf}, 2-4 \mathrm{X}$ the concentration in the alloy for $\mathrm{Ti}, 2-3 \mathrm{X}$ the concentration in the alloy for $\mathrm{Nb}$, and 1.3-2X the concentration in the alloy for Ta.

4. Most of these platelet phases were associated with cracks or crack-like voids which would be detected by normal NDI techniques.

5. Most of these platelet phases were found in the as-cast condition. Once the coarse platelets formed, they were not readily dissolved during solution heat treatment. Fine platelet phases that existed within and near $\gamma$ eutectic pools can be partially solutioned, and were thought to be the least harmful form of this phase.

6. Several of the platelet phases formed due to a reaction with the investment shell or core, creating a visible scale. If these surfaces can be inspected by NDI techniques, the platelets can be found and removed. Note that most internal surfaces will not meet this criterion.

7. Platelet phases are known to slightly reduce tensile strength and ductility in wheels and large vane segments.

\section{Recommendations}

Reduction of the platelet phases is a desired goal. While there is only some evidence to suggest the platelets are undesirable, there is no evidence to suggest the platelets are beneficial. Since there are many constraints in the casting process (especially including post-cast cooling rates), the only practical solution to elimination of the platelet phases is to 1) reduce the alloying elements that promote the platelet phases, including $\mathrm{Hf}, \mathrm{Ti}, \mathrm{Nb}$, and $\mathrm{Ta}$, in that order, 2) keep $C$ near specification maximums, 3 ) minimize $\mathrm{Zr}$, Si, and $\mathrm{P}$ from the alloy, and 4 ) reduce or eliminate reactions between the alloy and the shell or core.

\section{Acknowledgments}

The author would like to acknowledge help from several personnel at the Howmet Technical Center: Metallography was performed by D. Bakos, SEM was performed by Bo-Ping $\mathrm{Gu}$, and electron microprobe analyses were performed by $P$. Merewether. The expert work of these individuals is greatly appreciated. In addition, the author would also like to thank J. Mihalisin, P. Merewether, J. Grady, G. Cole, and F. Norris for several helpful discussions, and for reviewing the manuscript. Discussions with J. H. Wood of GE Power Generation and J. Radavich of Purdue Univ. (retired), were also helpful.

\section{References}

1. J. Fiedler, P. Follo, D. Wilson, unpublished data, AVCO Lycoming, 1980, used with permission.

2. K. Schneider (ABB Kraftwerke AG), "Advanced Blading", High Temperature Materials for Power Engineering 1990", Proceedings of a Conference at Liege, Belgium, September 1990, Kluwer Academic Publishers, p935.

3. P. W. Schilke, A. D. Foster, J. J. Pepe, and A. M. Beltran (GE-PG), "Advanced Materials Propel Progress in Land Base Gas Turbines", Adv. Mat. \& Proc.. April 1992, p22. 
4. M. Doner, J. A. Heckler (Allison), "Effects of Section Thickness and Orientation on the Creep-Rupture Properties of Two Advanced Single Crystal Alloys", Aerospace Tech. Conf. Long Beach, CA, Oct. 1985.

5. United Technologies Alloy Reference List, Aug. 1992.

6. The Superalloys, Edited by C. T. Sims and W. C. Hagel, Published by John Wiley \& Sons, 1972.

7. Superalloys II, Edited by C. T. Sims, N. S. Stoloff, and W. C. Hagel, John Wiley \& Sons, 1987.

8. The Nimonic Alloys and Other Nickel-Base High Temperature Alloys, Edited by $\mathrm{W}$. Betteridge and $\mathrm{J}$. Heslop, Published by Edward Arnold, 1974.

9. Metals Handbook 9th Edition (1985), Metallography and Microstructures, Wrought and Heat Resistant Alloys, Published by ASM, p310-311.

10. P. Willemin, and M. Durand-Charre, "Phase Equilibria in Multicomponent Alloy Systems", Superalloys 1988, Pub. by TMS, p723.

11. J.R.Mihalisin \& R.F.Decker, Trans AIME 218 (1960) p507.

12. R. F. Decker, "Strengthening Mechanisms in NickelBase Superalloys," presented at Steel Strengthening Mechanisms Symp., Zurich, Switzerland, May, 1969.

13. V. Biss and Bo-Ping Gu, Howmet Corp. (Tech. Genter), unpublished data, 1988.

14. Y. Zhu, S. Zhang, et. al., "A New Way to Improve the Superalloys", Superalloys 1992, Pub. by TMS, p145.

15. M. Emerson, Howmet Corp. (Ceramic and Coating Div.), unpublished research, 1980.

16. S. A. Knight, Howmet Corp. (LaPorte, IN., Casting Div.), unpublished research, 1981.
17. S.W.K. Shaw and M. J. Fleetwood, "New Nickel Base Investment Casting Alloys IN6201 and IN6203", Materials Science and Technology, Sept. 1989, Vol. 5, page 925 .

18. W. Esser (Siemens KWU), "Directional Solidification of Blades for Industrial Gas Turbines", Mat'ls for Advanced Power Engineering 1994, Edited by D. Coutsouradis et. al., Kluwer Academic Pub., 1994, p641.

19. G. K. Bouse, D. Bakos, and S. Renz, Howmet Corp. (Tech. Center), unpublished research, 1995.

20. S.W.K. Shaw, "Response of IN939 to Process Variations", Superalloys 1980, pub. by ASM, p275.

21. T.B.Gibbons and R.Stickler, "IN939: Metallurgy, Properties and Performance", High Temp. Alloys for Gas Turbines 1982, published by D. Reidel (1982), p369.

22. K. M. Delargy and G. D. W. Smith, "Phase Compositions and Phase Stability of Alloy IN939", ibid p705.

23. G. R. Cole II, Howmet Corp. (Tech. Center), unpublished research, 1995.

24. G. K. Bouse and D. Bakos, Howmet Corp., ibid, 1995.

25. S. A. Kriesel, Howmet Corp., ibid, 1992.

26. J. H. Wood, General Electric Co. Power Generation Division, private communication with the author, 1996.

27. G. K. Bouse and D. Bakos, Howmet Corp. unpublished research, 1995.

28. K. F. Lin, Y. L. Lin, and S. E. Hsu, "Interaction of Ceramic Shell Mold With Ni-Base Superalloys During Single Crystal Casting", Advanced Materials and Processing Techniques for Structural Applications, Ed. by T. Khan and A. Lasalmonie, Pub. by ONERA (1987) p285. 